\title{
Semiospheric transitions: A key to modelling translation
}

\author{
Edna Andrews, Elena Maksimova \\ Department of Slavic and Eurasian Studies, Duke University \\ Durham, 27708 North Carolina, USA \\ e-mails: eda@duke.edu; elena@duke.edu
}

\begin{abstract}
Lotman's contribution to semiotic theory, anthroposemiotics, the study of artistic texts and defining the relationship between language and culture represent some of the most powerful work produced within the Tartu-Moscow School of Semiotics. The importance of translation is one of the central principles that unites all of Lotman's work. In the following paper, we will consider Lotman's definition of translatability in the context of (1) the definition of semiospheric internal and external boundaries and the importance of crossing these boundaries, (2) the role of no fewer than two languages as a minimal unit of semiotic meaning-generation, (3) culture text-level generation of collective memory, and (4) the ever-present tension in the communication act. In our concluding section, we will offer an extended model of the communication act, based on the fundamental principles given in Jakobson, Sebeok and Lotman, in order to specify important moments of the translation process.
\end{abstract}

Ситуация, когда минимальной смыслопорождающей единицей является не один язык, а два, создает ичелую ичепь последствий. Прежде всего, сама природа интеллектуального акта может быть описана в терминах перевода, определение значения - перевод с одного языка на другой, причем внеязыковая реальность мыслится так же, как некоторый язык.

J. Lotman (1992a: 16)

1 A situation in which the minimal meaning-generating unit is not one language, but two, creates a whole chain of consequences. First of all, even the nature of the intellectual act could be described in terms of the translation, a definition of meaning as a translation from one language to another, whereas extra-lingual reality may be regarded as yet another type of language. 
Lotman's contribution to semiotic theory spans over four decades and has fundamentally changed the direction of structuralist approaches to the field of anthroposemiotics. In particular, it is Lotman's later works on the semiosphere and communication act models that are central to his contribution to a theory of translation. The focus of the following discussion will be to present the key concepts from Lotmanian theory that are pertinent to defining the translation-based properties of different types of communication and the generation of new meanings within the semiosphere.

\section{Semiosphere and its boundaries}

The Lotmanian focus on the analysis and construction of semiotic space required the development of a structural framework within which the process of the exchange of information, as well as degrees of information exchanged, could be explicated not only at the individual sign level, but at the system-based, network level. Such a space, which is a prerequisite for the semiotic act itself, was named the semiosphere (Lotman 1990: 123-124; 1992b: 12-13). The fundamental concepts associated with Lotman's semiosphere are:

(1) heterogeneity of the space, where the languages of the semiosphere are represented as a continuum that includes extremes of mutual untranslatability and complete mutual translatability (Lotman 1990: 125; 1992a: 14-16; 1992b: 11-24);

(2) asymmetry at multiple levels, including the internal structures, centre versus periphery and metalinguistic structures (Lotman 1990: 124-127; 1992a: 25-30; 1992b: 16-19);

(3) binary distinctions of internal and external spaces where these binary oppositions are pluralities (1990: 124; 1992b: 13-17);

(4) boundedness as the primary mechanism of semiosis where the boundaries themselves are most often defined as multiplicities of internal and external bilingual filters and membranes that facilitate permeability and fluidity and accelerate semiotic processes (Lotman 1990: 131-140; 1992b: 3-16);

(5) development of metalanguage is an inevitable resolution of a high level of organization of the semiosphere and facilitates selfdescription and the achievement of a higher level of organization, 
especially in the core, central areas, which directly affects the rate of dynamic development and processing of new information (Lotman 1990: 128; 1992b: 16-17). Semiospheric space is in constant flux, but the rates of change are defined relative to the various internal subspaces of the semiosphere itself.

There is often a question about whether or not the spaces beyond the boundaries of a specific semiosphere are "non-semiotic". In fact, the semiotic paradigm would argue that while the perspective from within a particular semiospheric space may often cast the spaces beyond the boundary as chaotic and unorganized, all spaces that may potentially engage with and be perceived by the semiosphere are by definition semiotic. Following Uexküll, non-semiotic spaces, if they were to exist, would necessarily be closed systems, which are static and always unknowable. While Lotman himself does use the term "nonsemiotic" (несемиотическое), we would suggest that Lotman is more focused on what he calls "foreign (or "other") semiotic" spaces (иносемиотическое) and its relationship with semiotic space (Lotman 1992b: 14). In fact, Lotman himself rejects similar terms in later works (cf. инокультурность is substituted for некультурность) in his work, "Theses Towards A Semiotics of Russian Culture" (Lotman 2002: 235-236).

One of the defining aspects of Lotman's semiosphere that is central to the current discussion on translation is the important role that bilingual filters, as components of the internal and external boundaries of the semiosphere, play in allowing a particular semiospheric space to come into contact with distinct and separate multiplicities of "foreign" semiotic spaces (Lotman 1992b: 13). It is the summation of bilingual translation filters that allows for the generation of new information, as well as the recycling of information from the past within the potentially infinite boundaries of internal semiotic space. And it is precisely the crossing over of internal and external semiospheric boundaries of multiple texts, which often appear to be untranslatable at first blush, that brings the most powerful realizations of new meanings within the semiosphere itself. 


\section{Signification and communication in action}

The inevitability of translation at all levels of semiotic space is one of the central operating properties of Lotman's theory. In fact, the importance of translation for the generation of meanings and as a fundamental part of perception itself are tenets common to both Lotman's anthroposemiotic theory and Uexküll's biosemiotic theory of the Umwelt (Uexküll 1982). When we recall Lotman's definition of the semiosphere

the semiotic space necessary for the existence and functioning of languages, not the sum total of different languages; in a sense the semiosphere has a prior existence and is in constant interaction with languages...a generator of information. (Lotman 1990: 123, 127)

it is imperative to remember that the minimal meaning-generating unit is at least two languages (Lotman 1992a: 16). By rejecting the possibility of semiotic space based on a single language, Lotman calls for a communication act that structurally reflects this minimum requirement. Lotman selects Jakobson's communication act model of six factors and six functions (Jakobson 1987 [1960]: 66-71) as the starting point in building the mechanism for communication within the semiosphere (see Figure 1). Jakobson's model is a dynamic representation of the minimum number of factors and functions that

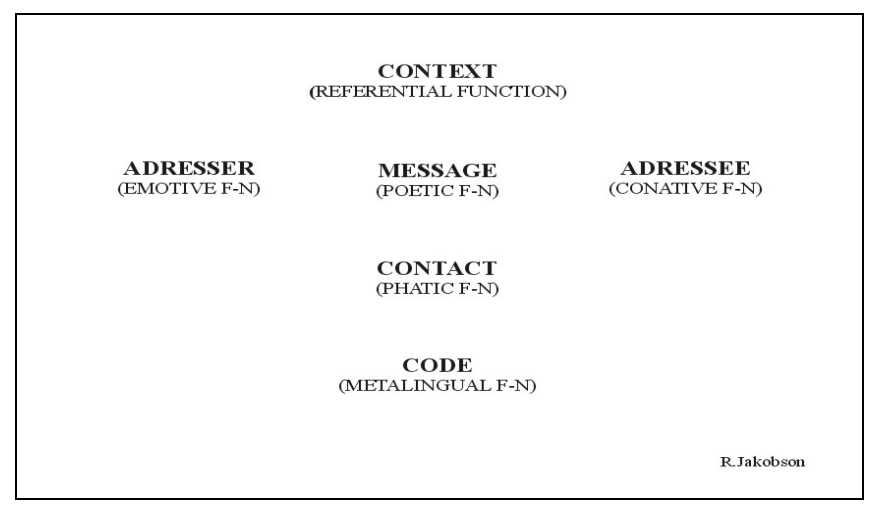

Figure 1. Jakobson's communication act model of six factors and six functions (adapted from Jakobson 1987: 66-71). 
are present in each and every speech act; each of these factors and functions are in a hierarchical relationship defined by constant internal renegotiation of dominance within each individual act.

For Lotman, all communication, as well as any and all cultural acts, are semiotic and as such, require some form of translation in order for meaning to be potentially generated. By using Jakobson's model as a basis for describing the communication act with the modification of (at least) doubling the factors and functions, Lotman demonstrates the inherent diversity of the minimal meaninggenerating units of the semiosphere. ${ }^{2}$

One of the consequences of Lotman's doubling of the fundamental features of the communication act is the central role played by translation from the simplest level of the communication act to the most complex level of semiospheric metatexts (Lotman 1992a: 16). There can be no communication act of any sort as a singular event; rather, all individual communication acts are dialogic in essence and require translation both as an internal mechanism of signification, as well as an external mechanism of signification and communication. However, while such an approach guarantees translation mechanisms, it does not guarantee the achievement of a coherent, meaningful result:

[...] non-comprehension (conversation in languages which are not fully identical) reveals itself to be just as valuable a meaning-making mechanism as comprehension. ${ }^{3}$ (Lotman 1992a: 16)

\section{Defining collective memory}

Semiotic approaches to the study of culture are often preoccupied with the construction and maintenance of the non-hereditary collective memory that is central to the definition and identity of cultural spaces and their languages. It is interesting to note that one may now find similar trends in the cognitive sciences and the study of human memory. Steven Rose, for example, consistently points out the

2 Sebeok (1991: 29) also contributes a modification to the Jakobsonian communication act model where the factor of context is doubled and is given both within the communication act and surrounding the entire event.

3 [...] непонимание (разговор на неполностью идентичных языках) представляется столь же ценным смысловым механизмом, что и понимание. 
importance of the interaction between collective and individual memory systems: "Individual our memories may be, but they are structured, their very brain mechanisms affected, by the collective, social nature of the way we as humans live" (Rose 1992: 60).

Collective memory is a mechanism for self-preservation and cultural propagation. Lotman's perspectives on the importance of oral and written culture texts as the basis for collective memory make an important contribution to our understanding of the role of language in this equation. Specifically, Lotman points out how written texts and the process of writing shift the burden of memory from the individual to an external symbolic system that is collectively maintained, while oral texts places a greater burden on individual memory systems (Lotman 1990: 246-247). In essence, language becomes the symbolic condenser between the varying levels of semiosis, as well as different segments of the time axis (Lotman 1990: 110). By combining the forces of collective memory and collective intellect, Lotman is able to construct a model of culture in which knowledge is maintained and transferred through time, and the actualization of codified information, as well as new information, are guaranteed (Lotman 1992b: 200, Andrews 2003: 157).

\section{Tension and the communication act}

Lotman's contribution of the importance of tension and explosion as important mechanisms of dynamic change within the semiosphere also play a central role in defining the individual level of speech acts and communication. Specifically, Lotman points to (1) the tension given in the asymmetric roles of the participants of the communication act and (2) the intersection, not identity, of the codes and memories implemented in communication acts (Lotman 1992a: 12-14). Lotman clearly explains the problem of two contradictory tensions that is produced in any given communication act:

[...] whilst a specific intersection between these spaces is admitted, at the same time an intersection between two contradictory tendencies appears: the struggle to facilitate understanding, which will always attempt to extend the area of the intersection, and the struggle to amplify the value of the communication, which is linked to the tendency of maximally amplifying the difference between $A$ and $B$. Thus, in normal lingual communication it is necessary 
to introduce the concept of tension, some form of resistance, which the spaces $A$ and $B$ use to oppose one another. (Lotman 1992a: 14$)^{4}$

Lotman goes on to argue that the "translation of the untranslatable turns out to be the carrier of highly valuable information" («перевод непереводимого оказывается носителем информации высокой ценности») (Lotman 1992a: 15). One could argue that Lotman creates a relative category of untranslatability, where in the end, everything is potentially translatable; however, extracting information and new meanings from these less accessible textual spaces increases the value of the content of the utterance. Furthermore, Lotman continues to remind us that the semiotic process does not guarantee a veridical outcome. Misunderstanding and breakdown in communication are as important as successful transmissions (Lotman 1992b: 18, Andrews 2003: 47-48). ${ }^{5}$ As mentioned above, "misunderstanding [...] is as valuable a meaning-generating mechanism as understanding" (Lotman 1992a: 16).

\section{Translation, translatability and the communication act model}

Roman Jakobson's famous work entitled "On Linguistic Aspects of Translation" (Jakobson 1971 [1959]: 260-266) is often cited in works dealing with translation theory. Jakobson's triad of primary translation modes includes intralingual, interlingual and intersemiotic. The central points of his work include a focus on code-based categories, both grammatical and lexical, and the impossibility of generating true equivalences in the translation process (Jakobson 1971: 261-265).

4 [...] допускается определенное пересечение этих пространств и одновременно пересечение двух противоборствующих тенденций: стремление к облегчению понимания, которое будет постоянно пытаться расширить область пересечения, и стремление к увеличению ценности сообщения, что связано с тенденцией максимально увеличить различие между $A$ и $B$. Таким образом, в нормальное языковое общение необходимо ввести понятие напряжения, некоего силового сопротивления, которое пространства $A$ и $B$ оказывают друг другу.

Lotman's autocommunication (автокоммуникация) also plays a significant role in the generation of new meaning. For a thorough discussion of this phenomenon, see Andrews (2003: 28-33). 
Lotman's doubling of the minimal kernel of the communication act also impacts the distinction between intralingual and interlingual translation, where intralingual moves toward (or even merges with) interlingual since there is no longer the option for only one language to exist; rather, the semiosphere requires at least two language. We may understand these languages on a variety of different levels: (1) the languages of the internal spaces of the semiosphere and the surrounding languages and spaces in which the semiosphere is embedded; (2) the fundamental distinction of I-I and I-S/he models of communication. As we mentioned in the previous section, Lotman often mentions spaces of untranslatability within subsections of the semiosphere:

Semiotic space appears before us as the multi-layered intersection of various texts, which are woven together in a specific layer characterized by complex internal relationships and variable degrees of translatability and spaces of untranslatability. ${ }^{6}$ (Lotman 1992a: 42)

Once again, it is necessarily the case that the internally distinct and bounded areas within the semiosphere are always potentially translatable. However, Lotman is reminding us that in the diachronic view of cultural spaces and texts, there may indeed be pockets of information that are no longer accessible to the contemporary cultural space due to a breakdown in knowledge of the codes of those internal spaces.

In order to contextualize the above discussion into a practical realization that can facilitate the translation process itself, especially with regard to the different types of cultural, semiotic and semiospheric transpositions that obligatorily occur within any cultural space, the authors propose a model that fully develops the notion of a minimum of two sets of factors and functions. By envisioning more than one addresser, addressee, context, contact, code and message (AACCCM), the notion of producing a target text (TT) with its own unique set of factors (that are necessarily different from the factors given by a source text (ST)) allows us to focus on the realistic outcomes of the translation process by reiterating the fact that each

6 Семиотическое пространство предстает перед нами как многослойное пересечение различных текстов, вместе складывающихся в определенный пласт, со сложными внутренними соотношениями, разной степенью переводимости и пространствами непереводимости. 
type of source text is generated from a specific set of factors (AACCCM), which must be recreated as a new set of features, including a different internal hierarchy, in any derived target text.

The fundamental goals of this hybrid communication act model include (1) minimizing the differences between the ST and TT, (2) reinforcing the importance of the dynamic, not static, entities that generate any text or communication act, and (3) demonstrating that communication acts are always present as textual ensembles.

The outline below is an example of how shifting internal hierarchies (where one or more factors may be dominant) between ST and TT may yield different types of translation:

1. Source Text [ST] (consisting of addresser, addressee, context, contact, code, message [AACCCM]) with an emphasis on doubling of the CODE results in a Target Text [TT] dominated by a maximal source-culture bias, often resulting in literal translation. (In other words, the focus of the translation process is to preserve the original code $\left(\mathrm{C}_{1}\right)$ of the ST as much as possible in the new (and different) code of the TT $\left(\mathrm{C}_{2}\right)$. The bias is to keep $\mathrm{C}_{2}$ (the dominant factor of the TT) as close to $C_{1}$ as possible.)

2. ST (AACCCM) with an emphasis on doubling of the CODE and MESSAGE results in a TT characteristic of faithful translation. (Here, code and message are dominant factors in generating the TT.)

3. ST (AACCCM) with an emphasis on doubling of the CODE, MESSAGE and ADDRESSER results in a TT characteristic of balanced translation.

4. ST (AACCCM) with an emphasis on doubling of the CODE, MESSAGE, ADDRESSER and ADDRESSEE results in a TT characteristic of idiomizing translations.

5. ST (AACCCM) with a doubling of all six factors yields a TT dominated by maximal target-culture bias, often resulting in free translation.

Thus, the hierarchy of the factors of the communication act and the doubling effect directly impact the type of translation that will result. 
Such a model of translation, which is an extension of the Jakobson/ Lotman models, makes a strong argument with regard to the importance of cultural information within a text and how it is nonsensical to attempt to speak of a text that is devoid of cultural information.

Lotman's contribution to the study of the interaction of language and culture and the structural mechanisms that define this interaction have significantly changed the field of semiotics not only in terms of the discipline itself, but in its ability to provide principles of analysis that are relevant across those disciplines that are engaged in elucidating the dynamic and complex interactions between language and culture.

\section{References}

Andrews, Edna 2003. Conversations with Lotman: Cultural Semiotics in Language, Literature, and Cognition. Toronto: University of Toronto Press.

Andrews, Edna; Maksimova, Elena 2009. Thinking Russian Translation. London: Routledge.

Hervey, Sándor; Higgins, Ian 2002. Thinking French Translation. London: Routledge.

Jakobson, Roman 1971 [1959]. On linguistic aspects of translation. In: Jakobson, Roman, Selected Writings II, Word and Language. The Hague: Mouton, 260266.

— 1987 [1960]. Linguistics and poetics. In: Pomorska, Krystyna; Rudy, Stephen (eds.), Language in Literature. Cambridge: Belknap Press of Harvard University Press, 62-94.

Lotman, Yury 1990. Universe of the Mind: A Semiotic Theory of Culture. (Shukman, Ann, trans.; Eco, Umberto, introduction.) Bloomington: Indiana University Press.

- 1992а. Культура и взрыв. Москва: Гнозис.

- 1992b. Избранные статьи в трех томах. Т. 1. Таллинн: Александра.

— 2002. Тезисы к семиотике русской культуры. In: Лотман, Юрий, Статьи по семиотике искусства. Санкт-Петербург: Академический проект, 226236.

Rose, Steven 1992. The Making of Memory: From Molecules to Mind. New York: Anchor Books, Doubleday.

Sebeok, Thomas 1991. A Sign is Just a Sign. Bloomington: Indiana University Press.

Uexküll, Jakob von 1982. The theory of meaning. Semiotica 42(1): 25-87. 


\section{Перемещение в семиосфере: ключ к моделированию процесса перевода}

Научные труды Ю. М. Лотмана затрагивают множество важнейших тем в области теории семиотики, в изучении и анализе художественного текста и в определении соотношения языка и культуры. Центральную роль в лотмановских работах играет концепция перевода, как объединяющий принцип его теории семиосферы. В данном анализе рассматриваются определения перевода и переводимости в контексте семиотической отграниченности (особенно учитывая специфику «семиотической границы»); многоязычность семиотического пространства и, в том числе, пространства, в которое погружена сама семиосфера; роль коллективной памяти и минимальные составляющие коммуникативного акта. В заключение предлагается моделирование разных типов перевода, основанное на базовых принципах коммуникативного акта, описанного в работах Якобсона, Себеока и Лотмана.

\section{Semiosfäärilised ülekanded: võti tõlke modelleerimiseks}

Juri Lotmani teadustööd hõlmavad paljusid semiootika teooria, kunstiteksti uurimise ja analüüsi ning keele ja kultuuri vahekorra määratlemisega seotud teemasid. Semiosfääri teooriat ühendaval tõlke kontseptsioonil on Lotmani töödes keskne roll. Artiklis vaadeldakse tõlke ja tõlgitavuse mõisteid semiootilise piiritletuse kontekstis (eelkõige "semiootilise piiri" spetsiifikast lähtuvalt), samuti semiootilise ruumi mitmekeelsust, kollektiivmälu rolli ja kommunikatsiooniakti minimaalseid osiseid. Pakutakse välja mudel erinevate tõlketüüpide eristamiseks, mis põhineb kommunikatsiooniakti neil alusprintsiipidel, mida on kirjeldanud oma töödes Roman Jakobson, Thomas Sebeok ja Juri Lotman. 